ISSN 1678-3921

Journal homepage: www.embrapa.br/pab

For manuscript submission and journal contents, access: www.scielo.br/pab
Anna Regina Tiago Carneiro(1凶) (D),

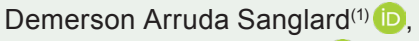
Alcinei Mistico Azevedo(1) (iD, Thiago Lívio Pessoa Oliveira de Souza(2) (D), Helton Santos Pereira(2) (iD, Leonardo Cunha Melo(2) (iD) and Pedro Crescêncio Souza Carneiro(3) (iD

(1) Universidade Federal de Minas Gerais, Instituto de Ciências Agrárias, Avenida Universitária, Campus Regional de Montes Claros, № 1.000, Universitário, CEP 39404-547 Montes Claros, MG, Brazil. E-mail: anna-regina@hotmail.com, demerson.ufmg@gmail.com, alcineimistico@hotmail.com

(2) Embrapa Arroz e Feijão, Rodovia GO-462, Km 12, Fazenda Capivara, Zona Rural, Caixa Postal 179, CEP 75375-000 Santo Antônio de Goiás, GO, Brazil. E-mail: thiago.souza@embrapa.br, helton.pereira@embrapa.br, leonardo.melo@embrapa.br

(3) Universidade Federal de Viçosa, Avenida Peter Henry Rolfs, s/no, Campus Universitário, CEP 36570-900 Viçosa, MG Brazil.

E-mail: carneiro@ufv.br

${ }^{凶}$ Corresponding author

Received

August 27, 2019

Accepted

May 26, 2020

How to cite

CARNEIRO, A.R.T.; SANGLARD, D.A.;

AZEVEDO, A.M.; SOUZA, T.L.P.O. de;

PEREIRA, H.S.; MELO, L.C.; CARNEIRO,

P.C.S. Fuzzy logic applied to different adaptability and stability methods in common bean. Pesquisa Agropecuária Brasileira, v.55, e01609, 2020. DOI: https://doi.org/10.1590/ S1678-3921.pab2020.v55.01609.

\section{Fuzzy logic applied to different adaptability and stability methods in common bean}

\begin{abstract}
The objective of this work was to evaluate the efficiency of the methods of Eberhart \& Russell and Lin \& Binns, modified for the automation of decision-making by fuzzy logic, in assessing the adaptability and stability of common bean (Phaseolus vulgaris) cultivars. Eighteen cultivars of the "carioca" commercial group were evaluated in 11 environments, in Brazil. All results were obtained by programming in the R software. The developed controllers were based on the fuzzy inference system developed by Mamdani. This system was modeled to enable interpretations of the method of Eberhart \& Russell alone or together with the modified method of Lin \& Binns. The controller based on Eberhart \& Russell and the one based on Eberhart \& Russell and Lin \& Binns identified the same cultivars as having general adaptability, but differed as to the classification of cultivars adapted to unfavorable environments. The BRSMG Pioneiro, BRS Pontal, IAC-Carioca Tybatã, and IPR Juriti cultivars presented general adaptability, whereas Campeão, Pérola, and BRS Estilo showed specific adaptability to favorable environments. The fuzzy logic methods used are efficient and allow the classification of all evaluated cultivars.
\end{abstract}

Index terms: computational intelligence, fuzzy logic and automation, genetic improvement, genotype by environment interaction.

\section{Lógica difusa aplicada a diferentes métodos de adaptabilidade e estabilidade no feijoeiro-comum}

Resumo - O objetivo deste trabalho foi avaliar a eficiência dos métodos de Eberhart \& Russell e Lin \& Binns, modificados para automação da tomada de decisão pela lógica difusa, na avaliação da adaptabilidade e da estabilidade de cultivares de feijoeiro-comum (Phaseolus vulgaris). Foram avaliadas 18 cultivares do grupo comercial carioca em 11 ambientes, no Brasil. Todos os resultados foram obtidos por programação no programa R. Os controladores desenvolvidos foram fundamentados no sistema de inferência difusa desenvolvido por Mamdani. Este sistema foi modelado para possibilitar interpretações do método de Eberhart \& Russell isoladamente ou em conjunto com o método de Lin \& Binns modificado. O controlador baseado em Eberhart \& Russell e o baseado em Eberhart \& Russell e Lin \& Binns identificaram as mesmas cultivares como tendo adaptabilidade geral, mas diferiram quanto à classificação das cultivares adaptadas a ambientes desfavoráveis. As cultivares BRSMG Pioneiro, BRS Pontal, IAC-Carioca Tybatã e IPR Juriti apresentaram adaptabilidade geral, enquanto Campeão, Pérola e BRS Estilo mostraram adaptabilidade específica a ambientes favoráveis. Os métodos de lógica difusa utilizados mostram eficiência e possibilitam a classificação de todas as cultivares avaliadas.

Termos para indexação: inteligência computacional, lógica difusa e automação, melhoramento genético, interação genótipo com ambiente. 


\section{Introduction}

Common bean (Phaseolus vulgaris L.) is a crop of great social and economic importance for Brazil, as it is a staple food in the diet of the population. It is cultivated in practically all regions of the country by small and large producers in different production systems and crop seasons (Vieira et al., 2013).

Due to the diverse conditions for common bean cultivation, the interaction between genotypes and environments can affect the chosen cultivars (Borém \& Miranda, 2013). Among the alternatives to better understand the effect of this interaction, stand out the analysis of genotype adaptability and phenotypic stability (Cruz et al., 2012).

Although important and essential in plant breeding, these methodologies are complicated and difficult to interpret, hindering the breeder's decision-making process. When there is a large number of genotypes and environments, for example, several parameters should be evaluated in isolation for each genotype, in order to select the best one. In this context, Carneiro et al. (2018) proposed fuzzy control systems as a tool to assist in decision-making in adaptability and stability studies. Fuzzy logic translates numeric values into verbal, vague, imprecise, and qualitative expressions common in communication, allowing to convert human experience into a computer-decodable language (Simões \& Shaw, 2007), which can be applied in automation in several areas. Therefore, fuzzy logic has great potential in studies of adaptability and stability, as a tool to interpret the parameters of the used methods and, consequently, to automate decisions that would be made by the breeders (Carneiro et al., 2018). This allows transforming a previously time-consuming and laborious process into a simple, practical, and fast one.

Even though the work of Carneiro et al. (2018) has shown the efficiency of the method of Eberhart \& Russell in the automation of decision-making, it is important to test it with other experimental data, as well as to check the efficiency of fuzzy logic for other methodologies, such as that of the method of Lin \& Binns.

The objective of this work was to evaluate the efficiency of the methods of Eberhart \& Russell and Lin \& Binns, modified for the automation of decisionmaking by fuzzy logic, in assessing the adaptability and stability of common bean cultivars.

\section{Materials and Methods}

The data used in the study were obtained from experiments carried out within the common bean breeding program of Embrapa Arroz e Feijão, with the following 18 common bean cultivars of the "carioca" commercial group: Alba, BRS 9435 Cometa, BRS Estilo, BRS Horizonte, BRSMG Majestoso, BRSMG Pioneiro, BRSMG Talismã, BRS Pontal, BRS Requinte, Campeão, SCS202 Guará, IAC-Carioca Tybatã, IPR Colibri, IPR Juriti, IPR Saracura, FTS Magnífico, Pérola, and Rubi.

The trials were conducted in 11 environments, in the municipalities of: Ponta Grossa, in the state of Paraná (255'40"S, 5009'48"W); Santo Antônio de Goiás, in the state of Goiás $\left(16^{\circ} 28^{\prime} 00^{\prime \prime} \mathrm{S}, 49^{\circ} 17^{\prime} 00^{\prime \prime} \mathrm{W}\right)$; and Uberlândia, in the state of Minas Gerais $\left(18^{\circ} 54^{\prime} 44^{\prime \prime S}\right.$, $\left.48^{\circ} 15^{\prime} 44^{\prime \prime} \mathrm{W}\right)$, in the rainy, dry, and winter crop seasons, in 2006, 2007, 2008, and 2010. The combination of each location, crop, and year was considered as a growing environment. Each environment, its climatic characteristics, and location are described in Table 1. The experimental design was a randomized complete block, with three replicates. The experimental units consisted of four lines of $4.0 \mathrm{~m}$, spaced at $0.50 \mathrm{~m}$. Productivity data were collected in the two central lines of the plots, whose grain yield was measured and converted, in $\mathrm{kg} \mathrm{ha}^{-1}$, to $13 \%$ humidity.

The data were subjected to the analysis of individual variance, according to the model: $Y_{i j}=\mu+G_{i}+B_{j}+\varepsilon_{i j}$, where $Y_{i j}$ is the value of each character for the ith genotype in the jth block; $\mu$ is the overall average; $G_{i}$ is the effect of the ith genotype; $B_{j}$ is the effect of the jth block; and $\varepsilon_{\mathrm{ij}}$ is the random error. The mean squares of the residues showed homogeneity between the experiments, with a ratio less than seven between the largest and the smallest mean square. This enabled a joint analysis, based on the following statistical model (Pimentel-Gomes, 2009): $\mathrm{Y}_{\mathrm{ijk}}=\mu+(\mathrm{b} / \mathrm{a})_{\mathrm{ijk}}+\mathrm{g}_{\mathrm{i}}+\mathrm{a}_{\mathrm{j}}+\mathrm{g}_{\mathrm{aij}}+\varepsilon_{\mathrm{ijk}}$, where $\mathrm{Y}_{\mathrm{ijk}}$ is the observation in the kth block, evaluated in the ith genotype and jth environment; $\mu$ is the overall average; $(\mathrm{b} / \mathrm{a})_{\mathrm{ijk}}$ is the effect of block $\mathrm{k}$ within environment $\mathrm{j}$; $\mathrm{g}_{\mathrm{i}}$ is the effect of genotype $i$; $a_{j}$ is the effect of environment $\mathrm{j}$; $\mathrm{g}_{\mathrm{aij}}$ is the effect of the interaction between genotype $\mathrm{i}$ and environment $\mathrm{j}$; and $\varepsilon_{\mathrm{ijk}}$ is the random error associated with observation ijk.

Analyses of adaptability and stability were also performed by the method of Eberhart \& Russell (1966) 
and the method of Lin \& Binns (1988) modified by Carneiro (1988).

The data were subjected to the analysis of adaptability and stability by the method of Eberhart \& Russell, based on the statistical model: $\overline{\mathrm{Y}}_{\mathrm{ij}}=\beta_{0 \mathrm{i}}+\beta_{\mathrm{ii}} \mathrm{I}_{\mathrm{j}}+\delta_{\mathrm{ij}}+\varepsilon_{\mathrm{ij}}$, where $\overline{\mathrm{Y}}_{\mathrm{ij}}$ is the estimated mean of cultivar $i$ in environment $j ; \beta_{0 \mathrm{i}}$ is the mean of genotype $i$ in all environments; $\beta_{1 \mathrm{i}}$ is the linear regression coefficient of cultivar $i$, which measures the response of the ith genotype to the variation of the environment; $\mathrm{I}_{\mathrm{j}}$ is the coded environmental index; $\delta_{\mathrm{ij}}$ is the deviation of the regression of the cultivar; and $\varepsilon_{\mathrm{ij}}$ is the mean experimental error.

For the modified method of Lin \& Binns, the $\mathrm{P}_{\mathrm{ij}}$ measure was decomposed into favorable $\left(\mathrm{P}_{\mathrm{if}}\right)$ and unfavorable $\left(\mathrm{P}_{\mathrm{id}}\right)$ environments.

For the favorable environments (environmental index $\geq 0$ ), the parameter was estimated as:

$$
\mathrm{P}_{\mathrm{if}}=\frac{\sum_{\mathrm{j}=1}^{\mathrm{f}}\left(\mathrm{Y}_{\mathrm{if}}-\mathrm{M}_{\mathrm{j}}\right)^{2}}{2 . \mathrm{f}}
$$

where $\mathrm{P}_{\text {if }}$ is the measure of adaptability and stability of genotype behavior in favorable environment $i$; $Y_{i j}$ is the productivity of the ith genotype, in the jth environment; $\mathrm{M}_{\mathrm{j}}$ is the maximum response among all genotypes in the environment; and $\mathrm{f}$ is the number of favorable environments.

For the unfavorable environments (environmental index $\leq 0$ ), the parameter was estimated as:

$$
P_{i d}=\frac{\sum_{j=1}^{d}\left(Y_{i j}-M_{. j}\right)^{2}}{2 . d}
$$

where $P_{\text {id }}$ is the measure of adaptability and stability of genotype behavior in unfavorable environment $i$; $\mathrm{Y}_{\mathrm{ij}}$ is the productivity of the ith genotype in the $\mathrm{jth}$ environment; $\mathrm{M}_{\mathrm{j}}$ is the maximum response among all genotypes in the environment; and $d$ is the number of unfavorable environments.

For the method of Eberhart \& Russell, a fuzzy controller, based on the fuzzy inference system proposed by Mamdani \& Assilian (1975), was developed. The input fuzzy linguistic variables used were: general mean parameter $\left(\beta_{0}\right)$, regression coefficient $\left(\beta_{1}\right)$, and coefficient of determination $\left(R^{2}\right)$. Fuzzy sets were generated for each variable through pertinence functions (Carneiro et al., 2018).

The general averages of the genotypes were standardized on a scale from 0 to 100 . Standardization was based on the normal distribution of data, overall mean value $(\mu)$, and standard deviation $(\sigma)$. The values associated with $\mu-3 \sigma$ were assigned the value of 0 , and those associated with $\mu+3 \sigma$ were assigned the value of 100 .

The values of $\beta_{1}$ were allocated into the following sets: less than 1, equal to 1 , and greater than 1, using Z-, $\pi$-, and S-shaped functions (Carneiro et al., 2018), respectively.

Table 1. Environments, climate data, crop season, and year of cultivation of the trials with common bean (Phaseolus vulgaris)

\begin{tabular}{|c|c|c|c|c|c|c|c|}
\hline \multirow[t]{2}{*}{ Environment } & \multirow[t]{2}{*}{ Location $^{(1)}$} & \multirow{2}{*}{$\begin{array}{c}\text { Elevation }^{(2)} \\
(\mathrm{m})\end{array}$} & \multicolumn{3}{|c|}{ Climate data (annual average) ${ }^{(3)}$} & \multirow{2}{*}{$\begin{array}{l}\text { Harvest } \\
\text { period }^{(5)}\end{array}$} & \multirow[t]{2}{*}{ Year } \\
\hline & & & Precipitation $^{(4)}(\mathrm{mm})$ & RH (\%) & Temperature $\left({ }^{\circ} \mathrm{C}\right)$ & & \\
\hline 1 & L1 & 956 & 473.7 & 76.4 & 16.5 & Rainy & 2006 \\
\hline 2 & L1 & 956 & 533.5 & 80.2 & 17.0 & Rainy & 2008 \\
\hline 3 & L1 & 956 & 418.6 & 73.0 & 16.1 & Rainy & 2010 \\
\hline 4 & L1 & 956 & 625.3 & 81.1 & 21.0 & Dry & 2007 \\
\hline 5 & L1 & 956 & 766.0 & 84.0 & 20.0 & Dry & 2010 \\
\hline 6 & $\mathrm{~L} 2$ & 823 & 226.1 & 55.5 & 22.5 & Winter & 2006 \\
\hline 7 & L2 & 823 & 255.2 & 57.2 & 22.2 & Winter & 2008 \\
\hline 8 & L2 & 823 & 202.3 & 50.5 & 23.5 & Winter & 2010 \\
\hline 9 & L3 & 870 & 142.0 & 62.2 & 20.2 & Winter & 2007 \\
\hline 10 & L3 & 870 & 310.2 & 67.2 & 20.0 & Winter & 2008 \\
\hline 11 & L3 & 870 & 1.283 .4 & 77.7 & 23.0 & Dry & 2008 \\
\hline
\end{tabular}
cultivars, of the "carioca" commercial group, carried out in three Brazilian municipalities in 2006, 2007, 2008, and 2010.

(1)L1, Ponta Grossa, in the state of Paraná; L2, Santo Antônio de Goiás, in the state of Goiás; and L3, Uberlândia, in the state of Minas Gerais. ${ }^{(2)}$ Data from Instituto Brasileiro de Geografia e Estatística (IBGE, 2016). ${ }^{(3)}$ Data from Instituto Nacional de Metereologia (INMET, 2016). ${ }^{(4)}$ Precipitation data were calculated based on the sum of the precipitation of the months of each harvest in the respective years. ${ }^{(5)}$ First harvest or rainy harvest, from August to November; second harvest or dry harvest, from December to March; and third harvest or winter harvest, from April to July. RH, relative humidity. 
For this classification, it was taken into account that genotypes with a relevance greater than $50 \%$, in the set equal to 1 , would present values of $\beta_{1}$ statistically equal to 1 by Student's t-test. The original $\beta_{1}$ values of each genotype, when subjected to the controller, were standardized. This standardization was based on the $95 \%$ confidence interval of probability based on the t-distribution, considering the null hypothesis that $\beta_{1}$ is equal to 1 . A value of -2 was assigned to the lower limit of the confidence interval and a value of 4 , to the upper limit. The values of $\mathrm{R}^{2}$ were allocated to low and high fuzzy sets using Z-shaped (zmf) and S-shaped (smf), functions, respectively.

For the fuzzy controller, an output linguistic fuzzy variable was generated, also based on the inference system proposed by Mamdani \& Assilian (1975), being called "Mamdani behavior". The obtained values were

Table 2. Fuzzy linguistic rules implemented in the hybrid fuzzy controller, based on the method of Eberhart \& Russell and the modified method of Lin \& Binns.

\begin{tabular}{|c|c|c|c|c|}
\hline \multicolumn{4}{|c|}{ Input $^{(1)}$} & \multirow{2}{*}{$\begin{array}{c}\text { Output } \\
\text { Behavior }\end{array}$} \\
\hline $\mathrm{P}_{\mathrm{if}}$ & $\mathrm{P}_{\mathrm{id}}$ & $\beta_{1}$ & $\mathrm{R}^{2}$ & \\
\hline Low & Low & Less than 1 & Low & Poorly adapted \\
\hline Low & Low & Less than 1 & High & Unfavorable \\
\hline Low & High & Less than 1 & Low & Poorly adapted \\
\hline Low & High & Less than 1 & High & Poorly adapted \\
\hline Low & Low & Equal to 1 & Low & Poorly adapted \\
\hline Low & Low & Equal to 1 & High & General \\
\hline Low & High & Equal to 1 & Low & Poorly adapted \\
\hline Low & High & Equal to 1 & High & Poorly adapted \\
\hline Low & Low & Greater than 1 & Low & Poorly adapted \\
\hline Low & Low & Greater than 1 & High & Favorable \\
\hline Low & High & Greater than 1 & Low & Poorly adapted \\
\hline Low & High & Greater than 1 & High & Favorable \\
\hline High & Low & Less than 1 & Low & Poorly adapted \\
\hline High & Low & Less than 1 & High & Unfavorable \\
\hline High & High & Less than 1 & Low & Poorly adapted \\
\hline High & High & Less than 1 & High & Poorly adapted \\
\hline High & Low & Equal to 1 & Low & Poorly adapted \\
\hline High & Low & Equal to 1 & High & Unfavorable \\
\hline High & High & Equal to 1 & Low & Poorly adapted \\
\hline High & High & Equal to 1 & High & Poorly adapted \\
\hline High & Low & Greater than 1 & Low & Poorly adapted \\
\hline High & Low & Greater than 1 & High & Poorly adapted \\
\hline High & High & Greater than 1 & Low & Poorly adapted \\
\hline High & High & Greater than 1 & High & Poorly adapted \\
\hline
\end{tabular}

${ }^{(1)} \mathrm{P}_{\mathrm{if}}$, measure of the adaptability and stability of genotype behavior in favorable environments; $\mathrm{P}_{\mathrm{id}}$, measure of the adaptability and stability of genotype behavior in unfavorable environments; $\beta_{1}$, regression coefficient; and $\mathrm{R}^{2}$, coefficient of determination. allocated into four performance-based fuzzy sets, classifying the evaluated genotypes according to their adaptability and stability, as: general, poorly adapted, unfavorable, and favorable (Table 2). The used fuzzy linguistic rules were based on those established by Carneiro et al. (2018), in which the combination of the fuzzy sets of each variable in the linguistic fuzzy rules, based on the inference system, allowed the development of controllers capable of determining the behavior of each studied cultivar. These rules, used in the developed fuzzy controller, were based on the interpretation of the parameters of the method of Eberhart \& Russell (Table 3).

The parameters estimated $\left(\Omega_{0}, \beta_{1}\right.$, and $\left.\mathrm{R}^{2}\right)$ for the 18 common bean cultivars were subjected to the controller in order to determine the behavior of these cultivars through the obtained aggregate values (pertinence).

A hybrid fuzzy controller of the Mamdani type was also developed, based on the methods of Eberhart \& Russell and Lin \& Binns. It was considered hybrid because it was based on the association of the $\beta_{1}$ and $R^{2}$ parameters of the method of Eberhart \& Russell with the values of $\mathrm{P}_{\mathrm{i}}\left(\mathrm{P}_{\mathrm{id}}\right.$ and $\left.\mathrm{P}_{\mathrm{if}}\right)$ of the modified method of Lin \& Binns.

The $\beta_{1}$ and $\mathrm{R}^{2}$ parameters were transformed into input variables similar to those used in the controller of the method of Eberhart \& Russell. In addition, the mean square parameters for favorable $\left(\mathrm{P}_{\text {if }}\right)$ and

Table 3. Fuzzy linguistic rules based on the behavior of the evaluated genotypes for adaptability and stability, using the method of Eberhart \& Russell adapted from Carneiro et al. (2018).

\begin{tabular}{|c|c|c|c|}
\hline \multirow[t]{2}{*}{ Average } & \multicolumn{2}{|c|}{ Input $^{(1)}$} & \multirow{2}{*}{$\begin{array}{c}\text { Output } \\
\text { Mamdani behavior }\end{array}$} \\
\hline & $\beta_{1}$ & $\mathrm{R}^{2}$ & \\
\hline Low & Less than 1 & Low & Poorly adapted \\
\hline Low & Less than 1 & High & Poorly adapted \\
\hline Low & Equal to 1 & Low & Poorly adapted \\
\hline Low & Equal to 1 & High & Poorly adapted \\
\hline Low & Greater than 1 & Low & Poorly adapted \\
\hline Low & Greater than 1 & High & Poorly adapted \\
\hline High & Greater than 1 & Low & Poorly adapted \\
\hline High & Less than 1 & High & Unfavorable \\
\hline High & Equal to 1 & Low & Poorly adapted \\
\hline High & Equal to 1 & High & General \\
\hline High & Greater than 1 & Low & Poorly adapted \\
\hline High & Greater than 1 & High & Favorable \\
\hline
\end{tabular}

${ }^{(1)} \beta_{1}$, regression coefficient; and $\mathrm{R}^{2}$, coefficient of variation. 
unfavorable $\left(\mathrm{P}_{\mathrm{id}}\right)$ environments were transformed into two variables similar to the mean variable of this same controller.

All data analysis was done by programming in the $\mathrm{R}$ software (R Core Team, 2016). The used programming algorithms are presented in Carneiro (2016).

\section{Results and Discussion}

Based on the method of Eberhart \& Russell, the cultivars with general adaptability were BRSMG Pioneiro, BRS Pontal, IAC-Carioca Tybatã, and IPR Juriti, i.e., they showed the highest values of pertinence in the general group (Table 4). This means that they met the parameters of the method to indicate an ideal cultivar, which include a high average for $\beta_{0}$, a $\beta_{1}$ equal to 1 , and a high $\mathrm{R}^{2}$ (Cruz et al., 2012). According to Cruz (2013), having a $\mathrm{R}^{2}$ above $80 \%$ is indicative of a greater stability. Therefore, these cultivars are capable of presenting good results both in favorable and unfavorable environments. In this group, the IPR Juriti cultivar can be considered promising, because it obtained the highest value of pertinence.

Most cultivars - Alba, BRS 9435 Cometa, BRS Horizonte, BRSMG Majestoso, BRSMG Talismã, BRS Requinte, SCS202 Guará, IPR Colibri, IPR Saracura, FTS Magnífico, and Rubi - were classified as poorly adapted because of their lower $\beta_{0}, \beta_{1}$, or $\mathrm{R}^{2}$. However, the Campeão, Pérola, and BRS Estilo cultivars presented specific adaptability to favorable environments, falling into the favorable group due to their high average $\beta_{0}$ and $\beta_{1}>1$. In addition, these cultivars had a $\mathrm{R}^{2}$ greater than $80 \%$, which is indicative of a high predictability (stability), and, therefore, are recommended when the goal is to increase productivity by improving the environment, especially of crops grown by large farmers using a high technological level.

Although the controller, based on the method of Eberhart \& Russell, did not identify cultivars with adaptability to unfavorable environments, IPR

Table 4. Input variables and classification of the behavior of 18 common bean (Phaseolus vulgaris) cultivars subjected to the fuzzy controller based on the method of Eberhart \& Russell ${ }^{(1)}$.

\begin{tabular}{|c|c|c|c|c|c|c|c|}
\hline \multirow[t]{2}{*}{ Cultivar } & \multicolumn{3}{|c|}{ Input $^{(1)}$} & \multicolumn{4}{|c|}{ Pertinence of behavior $(\%)^{(2)}$} \\
\hline & $\aleph_{0}\left(\mathrm{~kg} \mathrm{ha}^{-1}\right)$ & $\beta_{1}$ & $\mathrm{R}^{2}(\%)$ & $\mathrm{GE}$ & PA & FAV & UNF \\
\hline Alba & 1,756 & $1.03^{\mathrm{ns}}$ & 0.88 & 21 & 79 & 3 & 0 \\
\hline BRS 9435 Cometa & 1,811 & $0.99^{\mathrm{ns}}$ & 0.95 & 31 & 69 & 0 & 0 \\
\hline BRS Estilo & 2,102 & $1.13 *$ & 0.95 & 44 & 13 & 56 & 0 \\
\hline BRS Horizonte & 1,752 & $0.84 *$ & 0.82 & 21 & 62 & 0 & 21 \\
\hline BRSMG Majestoso & 1,880 & $0.99^{\text {ns }}$ & 0.89 & 45 & 55 & 0 & 0 \\
\hline BRSMG Pioneiro & 2,016 & $0.95^{\text {ns }}$ & 0.84 & 71 & 29 & 0 & 6 \\
\hline BRSMG Talismã & 1,851 & $1.05^{\mathrm{ns}}$ & 0.97 & 39 & 61 & 7 & 0 \\
\hline BRS Pontal & 2,112 & $1.11^{\mathrm{ns}}$ & 0.96 & 62 & 12 & 38 & 0 \\
\hline BRS Requinte & 1,835 & $0.88^{\text {ns }}$ & 0.78 & 35 & 59 & 0 & 35 \\
\hline Campeão & 2,079 & $1.17 *$ & 0.93 & 24 & 16 & 76 & 0 \\
\hline SCS202 Guará & 2,012 & $0.97^{\mathrm{ns}}$ & 0.70 & 15 & 73 & 0 & 1 \\
\hline IAC-Carioca Tybatã & 1,934 & $1.06^{\mathrm{ns}}$ & 0.97 & 58 & 42 & 13 & 0 \\
\hline IPR Colibri & 1,719 & $0.84 *$ & 0.85 & 16 & 66 & 0 & 16 \\
\hline IPR Juriti & 2,017 & $1.01^{\mathrm{ns}}$ & 0.96 & 74 & 26 & 1 & 0 \\
\hline IPR Saracura & 1,875 & $0.81 * *$ & 0.94 & 19 & 56 & 0 & 44 \\
\hline FTS Magnífico & 1,640 & $0.76^{* *}$ & 0.90 & 3 & 89 & 0 & 7 \\
\hline Pérola & 1,969 & $1.26^{* *}$ & 0.96 & 0 & 35 & 65 & 0 \\
\hline Rubi & 1,858 & $1.05^{\mathrm{ns}}$ & 0.88 & 40 & 60 & 10 & 0 \\
\hline
\end{tabular}

${ }^{(1)} \beta_{0}$, mean; $\beta_{1}$, regression coefficient; and $\mathrm{R}^{2}$, coefficient of determination. ${ }^{(2)} \mathrm{GE}$, general behavior; PA, poorly adapted; FAV, favorable; and UNF, unfavorable. * and **Significant by the t-test, at 5 and $1 \%$ probability, respectively, for the angular coefficient when assuming the null hypothesis $\beta_{1}=1$. ${ }^{\mathrm{n}}$ Nonsignificant, at $5 \%$ probability. 
Saracura presented the highest value of pertinence in the group classified as having unfavorable behavior, which can be explained by its low $\beta_{1}$ estimate. Therefore, this cultivar is the most suitable for unfavorable environments. This is important information, as it shows that the fuzzy methodology, not only allows to classify, but also to identify better genotypes by the magnitude of pertinence, as evidenced by Carneiro et al. (2018).

The fuzzy hybrid controller, based on the method of Eberhart \& Russell and Lin \& Binns (Table 5), classified the BRSMG Pioneiro, BRS Pontal, IACCarioca Tybatã, and IPR Juriti cultivars as of general adaptability due to their low $\mathrm{P}_{\text {if }}$ and $\mathrm{P}_{\text {id }}$, high average $\beta_{0}$ above the general average of $1.952 \mathrm{~kg} \mathrm{ha}^{-1}, \beta_{1}=1$, and elevated $\mathrm{R}^{2}$. In the method of Lin \& Binns, genotypes with lower $\mathrm{P}_{\text {if }}$ and $\mathrm{P}_{\text {id }}$ values, respectively, are considered ideal for favorable and unfavorable environments. Therefore, these cultivars can be recommended for both of these environments, i.e., for small- and largescale farming with a low and high technological level, respectively (Cruz et al., 2012). The IPR Juriti cultivar stood out for presenting the highest value of pertinence within this group.

The Campeão, Pérola, and BRS Estilo cultivars showed the highest values of pertinence in the group classified as favorable, with adaptability to favorable environments. This is due to their low $\mathrm{P}_{\mathrm{if}}$, high average $\beta_{0}$ above the general average of $1.952 \mathrm{~kg} \mathrm{ha}^{-1}$, and $\beta_{1}>1$ (Table 5).

Both the controller based on Eberhart \& Russell and the hybrid controller based on Eberhart \& Russell and Lin \& Binns identified the same cultivars with a similar significant behavior. However, there was a difference in the classification of the cultivars for unfavorable environments, since only the hybrid controller identified a cultivar - IPR Saracura - as being adapted to these environments due to its low $\mathrm{P}_{\text {id }}$ and $\beta_{1}<1$; therefore, this genotype is recommended for small farmers with few technological resources. These results show that, although the two used controllers are able to classify all cultivars according to the criteria of each method, the hybrid controller, based on the methods of Eberhart \& Russell and Lin \& Binns, was

Table 5. Input variables and classification of the behavior of 18 common bean (Phaseolus vulgaris) cultivars subjected to the fuzzy hybrid controller based on the method of Eberhart \& Russell and the modified method of Lin \& Binns ${ }^{(1)}$.

\begin{tabular}{|c|c|c|c|c|c|c|c|c|}
\hline \multirow{2}{*}{ Cultivar } & \multicolumn{4}{|c|}{ Input $^{(1)}$} & \multicolumn{4}{|c|}{ Pertinence of behavior $(\%)^{(2)}$} \\
\hline & $P_{\text {if }}$ & $P_{\text {id }}$ & $\beta_{1}$ & $\mathrm{R}^{2}(\%)$ & GE & PA & FAV & UNF \\
\hline Alba & 496371 & 178036 & $1.03^{\mathrm{ns}}$ & 0.88 & 12 & 71 & 3 & 12 \\
\hline BRS 9435 Cometa & 366225 & 149359 & $0.99^{\text {ns }}$ & 0.95 & 26 & 52 & 0 & 26 \\
\hline BRS Estilo & 132061 & 76490 & $1.13^{*}$ & 0.95 & 44 & 22 & 56 & 20 \\
\hline BRS Horizonte & 498622 & 166280 & $0.84 *$ & 0.82 & 17 & 62 & 0 & 17 \\
\hline BRSMG Majestoso & 340630 & 123456 & $0.99^{\text {ns }}$ & 0.89 & 45 & 52 & 0 & 45 \\
\hline BRSMG Pioneiro & 202048 & 97971 & $0.95^{\mathrm{ns}}$ & 0.84 & 65 & 35 & 0 & 28 \\
\hline BRSMG Talismã & 263076 & 151438 & $1.05^{\mathrm{ns}}$ & 0.97 & 25 & 64 & 7 & 25 \\
\hline BRS Pontal & 114641 & 59214 & $1.11^{\mathrm{ns}}$ & 0.96 & 62 & 18 & 38 & 18 \\
\hline BRS Requinte & 660903 & 85544 & $0.88^{\text {ns }}$ & 0.78 & 12 & 59 & 0 & 41 \\
\hline Campeão & 147445 & 62257 & $1.17^{*}$ & 0.93 & 24 & 21 & 76 & 21 \\
\hline SCS202 Guará & 399347 & 93933 & $0.97^{\mathrm{ns}}$ & 0.70 & 15 & 57 & 0 & 15 \\
\hline IAC-Carioca Tybatã & 239278 & 10093 & $1.06^{\mathrm{ns}}$ & 0.97 & 63 & 37 & 13 & 33 \\
\hline IPR Colibri & 695089 & 133407 & $0.84 *$ & 0.85 & 9 & 63 & 0 & 37 \\
\hline IPR Juriti & 166268 & 70809 & $1.01^{\mathrm{ns}}$ & 0.96 & 77 & 19 & 1 & 23 \\
\hline IPR Saracura & 393800 & 88380 & $0.81^{\mathrm{ns}}$ & 0.94 & 19 & 29 & 0 & 56 \\
\hline FTS Magnífico & 759300 & 145918 & $0.76 * *$ & 0.90 & 3 & 72 & 0 & 28 \\
\hline Pérola & 194102 & 146841 & $1.26^{* *}$ & 0.96 & 0 & 27 & 72 & 0 \\
\hline Rubi & 315347 & 172779 & $1.05^{\mathrm{ns}}$ & 0.88 & 14 & 56 & 10 & 14 \\
\hline
\end{tabular}

${ }^{(1)} \mathrm{P}_{\text {if }}$, measure of the adaptability and stability of genotype behavior in favorable environments; $\mathrm{P}_{\text {id }}$, measure of the adaptability and stability of genotype behavior in unfavorable environments; $\beta_{1}$, regression coefficient; and $\mathrm{R}^{2}$, coefficient of determination. ${ }^{(2)} \mathrm{GE}$, general behavior; PA, poorly adapted; FAV, favorable; and UNF, unfavorable. *and **Significant by the t-test, at the 5 and $1 \%$ probability, respectively, for the angular coefficient when assuming the null hypothesis $\beta_{1}=1$. ns Nonsignificant, at $5 \%$ probability. 
more complete. This may be explained by the fact that the association of these two methods results in a higher number of classification parameters and, consequently, in a greater discrimination power.

Therefore, the selection of common bean cultivars by fuzzy logic using both the methods of Eberhart \& Russell and Lin \& Binns is recommended due to the different principles applied and complementary information, which make it possible to effectively and safely identify the response of genotypes to environmental changes. This is an advantage in comparison with the work of Carneiro et al. (2018), which only considered the method of Eberhart \& Russel. The complementarity of those two methods was also evidenced by Nascimento et al. (2013) and Vasconcelos et al. (2015). However, these studies showed that there is a low correlation between the methods of Eberhart \& Russell and Lin \& Binns, indicating that using the method of Eberhart \& Russel, together with a nonparametric method, can provide complementary information about the phenotypic stability of the assessed cultivars.

Both the controller based on Eberhart \& Russell and the hybrid controller based on Eberhart \& Russell and Lin \& Binns were able to classify the cultivars as an experienced researcher would have when considering the obtained parameters. Carneiro et al. (2018) found similar results using fuzzy controllers to classify common bean genotypes for adaptability and stability, taking into account grain yield data. The correct classification by fuzzy controllers is due to the composition of input and output linguistic variables, which allow the experience of the operator to be codified in rules that can be used by the computer to interpret and provide accurate and useful information for decision-making (Simões \& Shaw, 2007). Therefore, fuzzy logic has a powerful ability to model the complex human logic (Türksen, 2007), making it superior to the other more classical statistical methodologies used in decision-making (Piterbarg, 2011; Viertl, 2011; Blanco-Fernández et al., 2013).

Besides allowing the classification of a genotype into a group, fuzzy controllers also show the pertinence of the genotypes to compose other groups. For example, the BRS Estilo cultivar was classified as suitable for a favorable environment (pertinence of 56), but also had a high pertinence (44) for the general behavior group (Table 5). This additional information is useful, according to Kuo et al. (2009), for the systematization of imprecise knowledge, which is important for genetic improvement. Even though no cultivars were recommended for unfavorable environments when considering only the Eberhart \& Russell method (Table 4), fuzzy logic showed that BRS Horizonte, BRS Requinte, and IPR Saracura had a high pertinence for this group. This indicates that these genotypes could be used as parents in breeding programs to obtain suitable genotypes for an unfavorable environment.

The results of the present study are indicative that the controller based on Eberhart \& Russell and the hybrid controller based on Eberhart \& Russell and Lin $\&$ Binns were useful and efficient to aid in the process of cultivar recommendation, based on established fuzzy rules. Therefore, this technique becomes a great ally to breeding programs because of its simplicity and automation capacity, especially when there is a large number of evaluated genotypes.

\section{Conclusions}

1. The BRSMG Pioneiro, BRS Pontal, IAC-Carioca Tybatã, and IPR Juriti common bean (Phaseolus vulgaris) cultivars present general adaptability, whereas Campeão, Pérola, and BRS Estilo show specific adaptability to favorable environments, and IPR Saracura is adapted to unfavorable environments.

2. Both the fuzzy controller based on Eberhart \& Russell and the hybrid controller based on Eberhart \& Russell and Lin \& Binns classify all cultivars correctly according to the estimated statistical parameters.

3. Fuzzy logic can be used to automate the classification of genotypes for adaptability and stability, which can reduce the unnecessary expenditure of time and human resources for breeding programs.

\section{Acknowledgments}

To Coordenação de Aperfeiçoamento de Pessoal de Nível Superior (Capes), for financial support; and to Embrapa Arroz e Feijão, for the used data.

\section{References}

BLANCO-FERNÁNDEZ, A.; CASALS, M.R.; COLUBI, A.; CORRAL, N.; GÁRCIA-BÁRZANA, M.; GIL, M.A.; GONZÁLEZ-RODRÍGUEZ, G.; LÓPEZ, M.T., LUBIANO, 
M.A.; MONTENEGRO, M.; RAMOS-GUAJARDO, A.B.; DE LA ROSA DE SÁA, S.; SINOVA, B. Random fuzzy sets: a mathematical tool to develop statistical fuzzy data analysis. Irarian Journal of Fuzzy Systems, v.10, p.1-28, 2013. DOI: https://doi.org/10.22111/IJFS.2013.609.

BORÉM, A.; MIRANDA, G.V. Melhoramento de plantas. 6.ed. rev. e ampl. Viçosa: UFV, 2013. 523p.

CARNEIRO, A.R.T. Lógica fuzzy na recomendação de cultivares de feijoeiro comum quanto à adaptabilidade e estabilidade. 2016. 125p. Dissertação (Mestrado) - Universidade Federal de Minas Gerais, Montes Claros.

CARNEIRO, P.C.S. Novas metodologias de análise da adaptabilidade e estabilidade de comportamento. 1998. 168p. Tese (Doutorado) - Universidade Federal de Viçosa, Viçosa.

CARNEIRO, V.Q.; PRADO, A.L. do; CRUZ, C.D.; CARNEIRO, P.C.S.; NASCIMENTO, M.; CARNEIRO, J.E. de S. Fuzzy control systems for decision-making in cultivars recommendation. Acta Scientiarum. Agronomy, v.40, e39314, 2018. DOI: https://doi.org/10.4025/actasciagron.v40i1.39314.

CRUZ, C.D. Genes: a software package for analysis in experimental statistics and quantitative genetics. Acta Scientiarum Agronomy, v.35, p.271-276, 2013. DOI: https://doi.org/10.4025/actasciagron. v35i3.21251.

CRUZ, C.D.; REGAZZI, A.J.; CARNEIRO, P.C.S. Modelos biométricos aplicados ao melhoramento genético. 4.ed. Viçosa: UFV, 2012. 514p.

EBERHART, S.A.; RUSSELL, W.A. Stability parameters for comparing varieties. Crop Science, v.6, p.36-40, 1966. DOI: https://doi.org/10.2135/cropsci1966.0011183X000600010011x.

IBGE. Instituto Brasileiro de Geografia e Estatística. [Portal Cidades]. Available at: <https://cidades.ibge.gov.br/>. Accessed on: Jan. 142016.

INMET. Instituto Nacional de Meteorologia. BDMEP: Banco de Dados Meteorológicos para Ensino e Pesquisa. Available at: $<$ http://www.inmet.gov.br/portal/index.php?r=bdmep/bdmep $>$. Accessed on: Jan. 122016.

KUO, T.-C.; WU, H.-H.; SHIEH, J.-I. Integration of environmental considerations in quality function deployment by using fuzzy logic. Expert Systems with Applications, v.36, p.1748-7156, 2009. DOI: https://doi.org/10.1016/j.eswa.2008.08.029.
LIN, C.S.; BINNS, M.R. A superiority measure of cultivar performance for cultivar $\mathrm{x}$ location data. Canadian Journal of Plant Science, v.68, p.193-198, 1988. DOI: https://doi.org/10.4141/ cjps88-018.

MAMDANI, E.H.; ASSILIAN, S. An experiment in linguistic synthesis with a fuzzy logic controller. International Journal of Man-Machine Studies, v.7, p.1-13, 1975. DOI: https://doi.org/10.1016/S0020-7373(75)80002-2.

NASCIMENTO, M.; NASCIMENTO, A.C.C.; CIRILLO, M.A.; FERREIRA, A.; PETERNELLI, L.A.; PAULA, R.F. de. Association between responses obtained using adaptability and stability methods in alfalfa. Semina: Ciências Agrárias, v.34, p.2545-2554, 2013. DOI: https://doi.org/10.5433/1679$0359.2013 \mathrm{v} 34 \mathrm{n} 6 \mathrm{p} 2545$.

PIMENTEL-GOMES, F. Curso de estatística experimental. 15.ed. Piracicaba: ESALQ, 2009. 451p. (Biblioteca de Ciências Agrárias Luiz de Queiroz, 15).

PITERBARG, L.I. Parameter estimation from small biased samples: fuzzy sets vs statistics. Fuzzy Sets and Systems, v.170, p.1-21, 2011. DOI: https://doi.org/10.1016/j.fss.2011.01.010.

R CORE TEAM. R: a language and environment for statistical computing. Vienna: R Foundation for Statistical Computing, 2016.

SIMÕES, M.G.; SHAW, I.S. Controle e modelagem fuzzy. 2.ed. rev. e ampl. São Paulo: Blucher, 2007.

TÜRKSEN, I.B. Meta-linguistic axioms as a foundation for computing with words. Information Sciences, v.177, p.332-359, 2007. DOI: https://doi.org/10.1016/j.ins.2006.03.002.

VASCONCELOS, F.M.T. de; VASCONCELOS, R.A. de; LUZ, L.N. da; CABRAL, N.T.; OLIVEIRA JÚNIOR, J.O.L. de; SANTIAGO, A.D.; SGRILLO, E.; FARIAS, F.J.C.; MELO FILHO, P. de A.; SANTOS, R.C. dos. Adaptabilidade e estabilidade de genótipos eretos de amendoim cultivados nas regiões Nordeste e Centro-Oeste. Ciência Rural, v.45, p.1375-1380, 2015. DOI: https://doi.org/10.1590/0103-8478cr20140414.

VIEIRA, C.; PAULA JÚNIOR, T.J. de; BORÉM, A. (Ed.). Feijão. 2.ed. atual. Viçosa: UFV, 2013. 600p.

VIERTL, R. Statistical methods for fuzzy data. Vienna: J. Wiley, 2011. 268p. DOI: https://doi.org/10.1002/9780470974414. 